HELMINTHOLOGIA, 53, 1: 62 - 75, 2016

\title{
Morphological and molecular characterization of Xiphinema species from Shenzhen, China
}

\author{
Y. ZENG ${ }^{1,2 *}$, W. YE ${ }^{3}$, Z. ZHANG ${ }^{1}$, H. SUN ${ }^{1}$, L. YONG ${ }^{4}$, Y. HUANG $^{5}$, K. ZHAO ${ }^{4}$, H. LIANG ${ }^{4}$, J. KERNS $^{2 *}$
}

\begin{abstract}
${ }^{1}$ Department of Plant Protection, Zhongkai University of Agriculture and Engineering, Guangzhou 510225, People's Republic of China, "E-mail: zys65@163.com; 2Department of Plant Pathology, North Carolina State University, Raleigh, NC 27695-7613, USA, *E-mail: jpkerns@ncsu.edu; ${ }^{3}$ ematode Assay Section, Agronomic Division, North Carolina Department of Agriculture and Consumer Services, Raleigh, NC 27607, USA; " ${ }^{2}$ henzhen Environmental Monitoring Center, Shenzhen 518049, People's Republic of China; ${ }^{5}$ College of Life Sciences, Zhongkai University of Agriculture and Engineering, Guangzhou 510225, People's Republic of China
\end{abstract}

\section{Article info}

Received May 12, 2015 Accepted August 31, 2015

\begin{abstract}
Summary
During a nematode biodiversity survey from 2012 to 2014 in Shenzhen, China, ten nematode populations (SZX1301-SZX1310) of Xiphinema were recovered from rhizosphere of different plants, namely Acacia mangium (SZX1306), A. confuse (SZX1309), Blechnum orientale (SZX1301, SZX1302, SZX1307, SZX1308), Litchi chinensis (SZX1304, SZX1310) in Tianxinshan and Gleichenia linearis (SZX1303, SZX1305) in Yangmeikeng environmental monitoring sites. Morphological and molecular profiles of these populations were determined. Three species of Xiphinema, i.e., $X$. hunaniense Wang \& Wu, 1992, X. brasiliense Lordello, 1951 and X. americanum Cobb, 1913 sensu lato were identified using morphological characters and molecular data of partial 18S and 28S D2-D3 rDNA expansion segments. Four populations (SZX1301-SZX1304) were $X$. hunaniense, one population (SZX1305) X. brasiliense, and five populations (SZX1306-SZX1310) X. americanum s.l.. Phylogenetic analysis based on sequences of the 28S rDNA D2-D3 expansion segment revealed these three species are all distinct species and supported a close relationship with their corresponding species. This is the first report of $X$. hunaniense, $X$. brasiliense and $X$. americanum s.I. in their hosts except for $L$. chinensis.
\end{abstract}

Keywords: Xiphinema spp.; Acacia mangium; Acacia confuse; Blechnum orientale; Gleichenia linearis; Litchi chinensis; $28 \mathrm{~S}$ rDNA; dagger nematode

\section{Introduction}

The genus Xiphinema Cobb, 1913 belonging to the family Longidoridae represents ectoparasitic root nematodes commonly known as the dagger nematode. There are approximately 260 nominal species in the genus to date (Gutiérrez-Gutiérrez et al., 2012). They are typically divided into two groups, namely $X$. americanum-group with about 50 species and non- $X$. americanum-group (Loof \& Luc, 1990; Lamberti et al., 2000). The genus Xiphinema includes phytopathogenic species that damage a large number of wild and cultivated plants through direct feeding on root cells and transmission of several plant-pathogenic viruses (Taylor
\& Brown, 1997). It is of economic importance on grape, strawberry, hops, fruit trees and other crops. Nine species of Xiphinema have been shown to transmit nepoviruses (Decraemer \& Robbins, 2007). Some species in the $X$. americanum-group can serve as vectors of several important plant viruses including Tabacco ringspot virus, Tomato ringspot virus, Cherry rasp leaf virus and Peach rosette mosaic virus that damage a wide range of crops (Taylor \& Brown, 1997). Several species in the group are listed as quarantine organisms by some countries or regions such as the European and Mediterranean Plant Protection Organization. Therefore, accurate identification of the genus to the species level is crucial to implement appropriate control measures for these nematodes. 
Currently, species identification of this genus is mainly based on morphological features and morphometrics. However, species belonging to Xiphinema americanum-group show conserved morphology and overlapping morphometrics (Coomans et al., 2001; Gutiérrez-Gutiérrez et al., 2012). Thus, DNA-based approaches including ribosomal DNA such as the 18S, D2-D3 expansion segments of 28S, ITS regions, and mitochondrial DNA have been employed for the molecular characterization and reconstruction of phylogenetic relationships within Xiphinema (Oliveira et al., 2004; Ye et al., 2004; He et al., 2005; Lazarova et al., 2006; Wu et al., 2007; Gutiérrez-Gutiérrez et al., 2012, 2013).

Some species of the genus Xiphinema are distributed worldwide, whereas others have limited distribution (Coomans, 1996; Coomans et al., 2001; Gutiérrez-Gutiérrez et al., 2012). So far, 14 species of Xiphinema (X. americanum Cobb, 1913, X. brasiliense Lordello, 1951, X. brevicolle Lordello \& Costa, 1961, X. diffusum Lamberti \& Blève-Zacheo, 1979, X. elongatum Schuurmans Stekhoven \& Teunissen, 1938, X. hunaniense Wang \& Wu, 1992, X. imitator Heyns, 1965, X. incognitum Lamberti \& Blève-Zacheo, 1979, X. insigne Loos, 1949, X. luci Lamberti \& Bleve-Zacheo, 1979; X. oxycaudatum Lamberti \& Blève-Zacheo, 1979, X. radicicola Goodey, 1936, X. taylori Lamberti, Ciancio, Agostinelli \& Coiro, 1992, $X$. thornei Lamberti \& Golden, 1986) were reported in China (Luo et al., 2001; Pan et al., 2000; Teng et al., 2013; Wang et al., 1996; Wu, 2007; Xu et al., 1995; Zheng \& Brown, 1999).

During a survey of nematode biodiversity in Yangmeikeng and Tianxinshan environmental monitoring sites in Shenzhen, China in 2012 - 2014, ten Xiphinema populations (designated as SZX1301 - SZX1310) were recovered from the rhizosphere collected from five plant species including Blechnoid (Blechnum orientale L.), Awn dichotoma (Gleichenia linearis Clarke.), Lychee (Litchi chinensis Sonn.), Acacia acacia (Acacia mangium Willd.) and Taiwan acacia (A. confusa Merr.).

The main objectives of this study were to: (i) identify the species of ten Xiphinema populations based on morphological and molecular approaches; and (ii) investigate their phylogenetic relationships with other species in the genus based upon sequence analysis of the 28S D2-D3 rDNA.

\section{Materials and Methods}

\section{Sampling and Morphological Study}

Soil samples were collected from the rhizosphere at a depth of $15-30 \mathrm{~cm}$ of different plants, namely Acacia acacia, Taiwan acacia, Blechnoid, Lychee in Tianxinshan and Awn dichotoma in Yangmeikeng environmental monitoring sites. Ten nematode populations from the rhizosphere of five plants in two environmental monitoring sites, Shenzhen, China, were presented in Table 1. Nematodes were extracted by a sieving and decanting method (Brown \& Boag, 1988). Specimens were heat-killed, fixed in $3 \%$ formaldehyde and processed to glycerin by the formalin-glycerin method (Hooper, 1970; Golden, 1990). Specimen preparation and measurements were as described in Golden \& Birchfield (1972). Measurements of nematodes were performed with the aid of a camera lucida and a stage micrometer. The morphometric data were processed using Excel software (Ye, 1996). Photomicrographs were taken with a Leica video camera (DFC490) fitted on a Leica microscope (DM4000B), and edited using Adobe Photoshop CS5. Morphological identification of specimens for Xiphinema was done using the polytomous keys provided by Lamberti et al. (2000, 2004) and Loof \& Luc (1990), with corresponding species descriptions.

\section{Molecular Study}

DNA extraction, amplification and sequencing: For each population, three females were hand-picked into distilled water for DNA extraction, amplification, and sequencing. They were placed into $50 \mu$ of worm lysis buffer (WLB) containing Proteinase $\mathrm{K}$ for DNA extraction (Williams et al., 1992). DNA samples were stored at $-20^{\circ} \mathrm{C}$ until used as a PCR template.

The primers for small subunit $18 \mathrm{~S}$ amplification and DNA sequencing were forward primer $18 S 965$ (5' GGCGATCAGATAC-

Table 1. Species and populations of Xiphinema in this study

\begin{tabular}{|c|c|c|c|c|c|}
\hline Species & $\begin{array}{l}\text { Population } \\
\text { code }\end{array}$ & Locality & Host plant & $\begin{array}{c}\text { 18S Accession } \\
\text { No. }\end{array}$ & $\begin{array}{c}\text { 28S D2-D3 Accession } \\
\text { No. }\end{array}$ \\
\hline Xiphinema hunaniense & SZX1301 & Tianxinshan, Shenzhen & Blechnum orientale & KP793036 & KP793046 \\
\hline Xiphinema hunaniense & SZX1302 & Tianxinshan, Shenzhen & Blechnum orientale & KP793037 & KP793047 \\
\hline Xiphinema hunaniense & SZX1303 & Yangmeikeng, Shenzhen & Gleichenia linearis & KP793038 & KP793048 \\
\hline Xiphinema hunaniense & SZX1304 & Tianxinshan, Shenzhen & Litchi chinensis & KP793039 & KP793049 \\
\hline Xiphinema brasiliense & SZX1305 & Yangmeikeng, Shenzhen & Gleichenia linearis & KP793040 & KP793050 \\
\hline Xiphinema americanum s.I. & SZX1306 & Tianxinshan, Shenzhen & Acacia mangium & KP793041 & KP793051 \\
\hline Xiphinema americanum s.I. & SZX1307 & Tianxinshan, Shenzhen & Blechnum orientale & KP793042 & KP793052 \\
\hline Xiphinema americanum s.I. & SZX1308 & Tianxinshan, Shenzhen & Blechnum orientale & KP793043 & KP793053 \\
\hline Xiphinema americanum s.I. & SZX1309 & Tianxinshan, Shenzhen & Acacia confuse & KP793044 & KP793054 \\
\hline Xiphinema americanum s.l. & SZX1310 & Tianxinshan, Shenzhen & Litchi chinensis & KP793045 & KP793055 \\
\hline
\end{tabular}


CGCCCTAGTT 3') and reverse primer 18S1573R (5' TACAAAGGGCAGGGACGTAAT 3') (Mullin et al., 2005). Primers for large subunit 28S amplification and DNA sequencing were forward primer D2a (5' ACAAGTACCGTGAGGGAAAGTTG 3') and reverse primer D3b (5' TGCGAAGGAACCAGCTACTA 3') (Nunn, 1992).

The $25 \mu \mathrm{l}$ PCR was performed using TaqMix DNA polymerase (Guangzhou Dongsheng Biotech Ltd., Guangzhou, China) according to the manufacturer's protocol. The thermal cycler program for PCR was as follows: denaturation at $95^{\circ} \mathrm{C}$ for 5 min followed by 35 cycles of denaturation at $94{ }^{\circ} \mathrm{C}$ with $30 \mathrm{~s}$; annealing at $55^{\circ} \mathrm{C}$ for $45 \mathrm{~s}$, and extension at $72^{\circ} \mathrm{C}$ for $2 \mathrm{~min}$. A final extension was performed at $72{ }^{\circ} \mathrm{C}$ for $10 \mathrm{~min}$ (Ye et al., 2007).

PCR products were cleaned using an EZ Spin Column DNA Gel Extraction Kit (Bio Basic Inc., Markham, Ontario, Canada) according to the manufacturer's protocol before being sequenced by Shanghai Sangon Biological Engineering Technology and Service Co., Ltd. (Shanghai, China) using an ABI PRISM 3730 sequencing system.
Phylogenetic analysis: The nematode sequences from this project were deposited in GenBank. We used DNA sequences with the highest matches with our populations from the GenBank database for phylogenetic analysis. DNA sequences were aligned using ClustalW (http://workbench.sdsc.edu, Bioinformatics and Computational Biology Group, Department of Bioengineering, UC San Diego, San Diego, CA, USA). The model of base substitution in the $28 \mathrm{~S}$ rDNA sets was evaluated using MODELTEST version 3.06 (Posada \& Crandall, 1998). The Akaike-supported model (GTR), the proportion of invariable sites (I), and the gamma distribution shape parameters and substitution rates $(G)$ were used in phylogenetic analyses. Bayesian analysis was performed to confirm the tree topology for each gene separately using MrBayes 3.1.0 (Huelsenbeck \& Ronquist, 2001) running the chain for $10^{6}$ generations and setting the 'burn in' at 1000. We used MCMC (Markov Chain Monte Carlo) methods within a Bayesian framework to estimate the posterior probabilities of the phylogenetic trees (Larget \& Simon, 1999) using the $50 \%$ majority-rule.
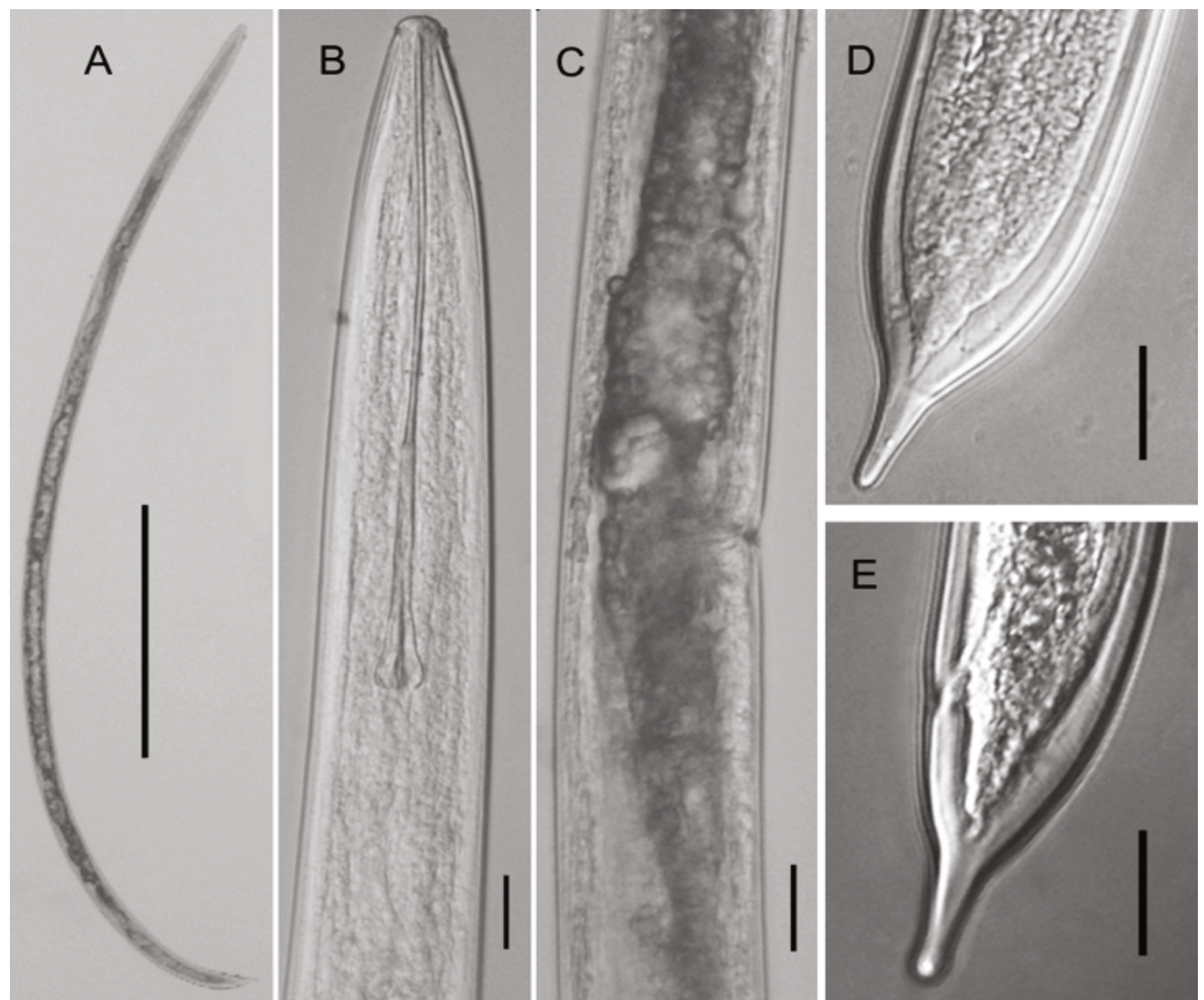

Fig. 1. Light micrographs of Xiphinema hunaniense from Blechnum orientale. A: Female entire body; B: Female anterior body; C: Reproductive system of female (in ventral view); D: Female tail (in ventral view); E: Female tail (in lateral view). Scale bars: $A=50 \mu \mathrm{m} ; B-E=10 \mu \mathrm{m}$ 


\section{Results}

Through this study, four nematode populations (SZX1301 SZX1304) were identified as Xiphinema hunaniense, one population (SZX1305) as X. brasiliense, and five populations (SZX1306 - SZX1310) as X. americanum s.l. (Table 1), representing the first report of these three species from the above-mentioned plant hosts except for lychee.

\section{Morphological description}

Morphometrics of females of ten populations of Xiphinema are presented in Table 2. Four populations (SZX1301 - SZX1304) of $X$. hunaniense are identical each other. All five populations of $X$. americanum s.I. (SZX1306 - SZX1310) showed little variation at morphometrics and molecular characteristics, thus considered different geographical populations belonging to the same species.
Xiphinema hunaniense Wang \& Wu, 1992

(Fig. 1, Tables 1 \& 2)

Female: Body $1810-2400 \mu \mathrm{m}$ long, tapering slightly towards anterior and tail region, posterior end arcuate ventrally when heat-killed. Body cuticle smooth. Lip region $10-12 \mu \mathrm{m}$ in diam., slightly offset from body profile. Amphids stirrup-shaped, with slitlike apertures. Stylet $173-193 \mu \mathrm{m}$ long. Guide ring $86-108 \mu \mathrm{m}$ from anterior end. Pharynx typical of genus. Vulva a transverse slit, anterior, occupies $23 \%-28 \%$ of total body length, vagina thick-walled, occupying up to $50 \%$ of body width. Reproductive system monodelphic, with a posterior reflexed gonad. Uterus short and undifferentiated, "Z"-organ absent. Tail dorsally conoid, slightly convex dorsally and concave ventrally, with a digitate, elongated peg (11 - $20 \mu \mathrm{m}$ long), with three caudal pores on each side of tail (one on each at beginning of tail terminus, the other two on the dorsal side near anus).

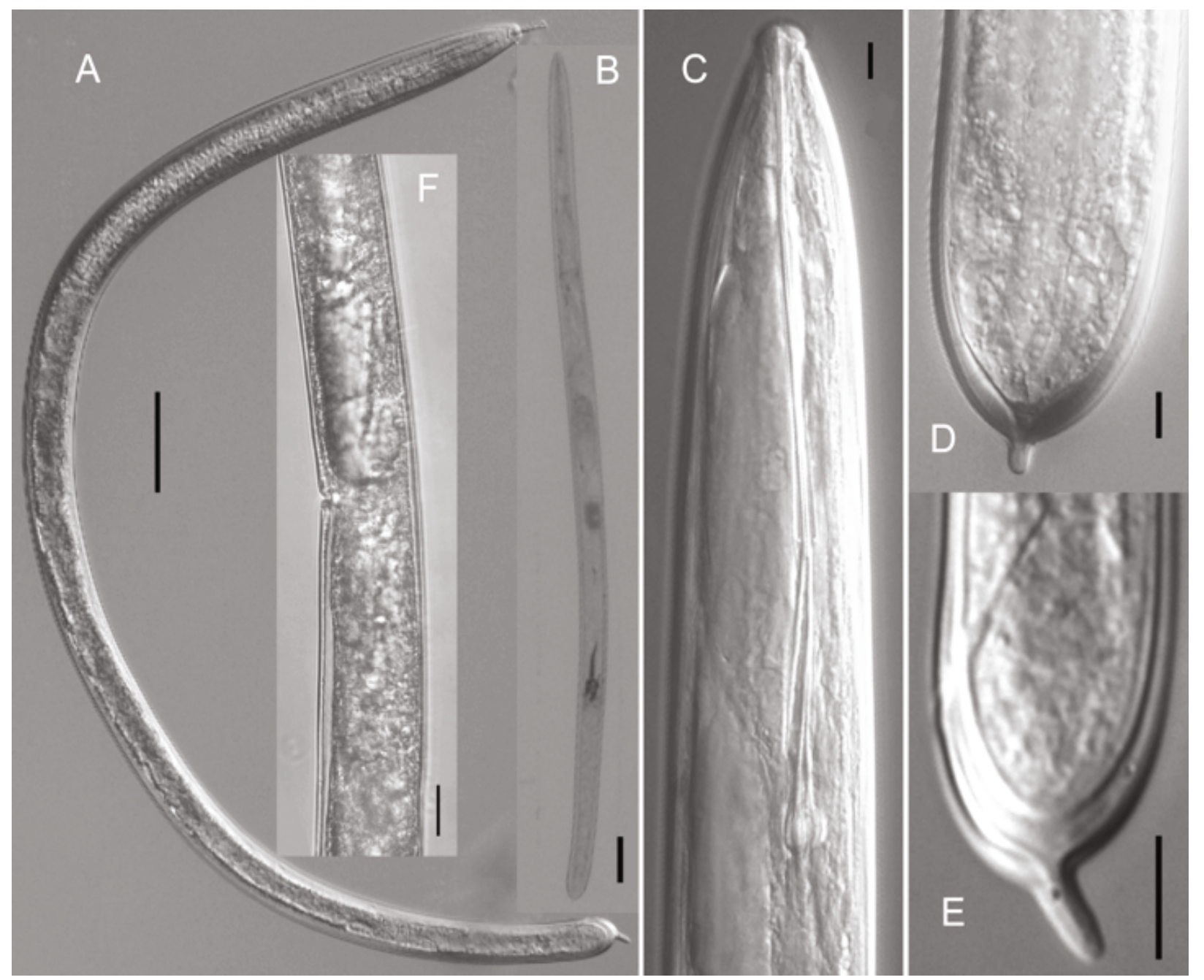

Fig. 2. Light micrographs of female Xiphinema brasiliense from Gleichenia linearis. A, B: Entire body; C: Anterior body; D: Tail in ventral view; E: Tail in lateral view; F: Reproductive system. Scale bars: $A=500 \mu \mathrm{m} ; \mathrm{B}, \mathrm{C}, \mathrm{E}=20 \mu \mathrm{m} ; \mathrm{D}=10 \mu \mathrm{m}$ 


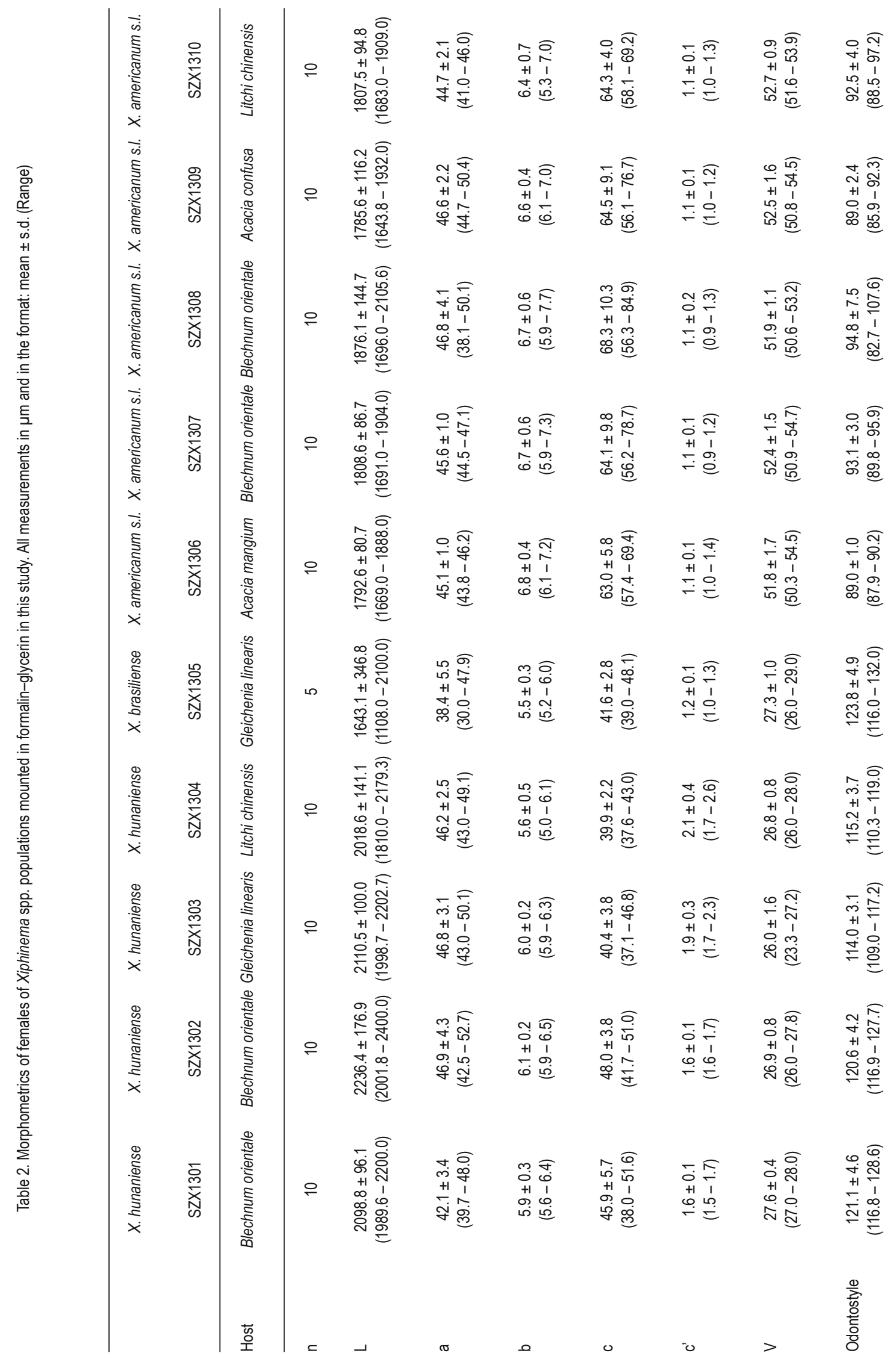




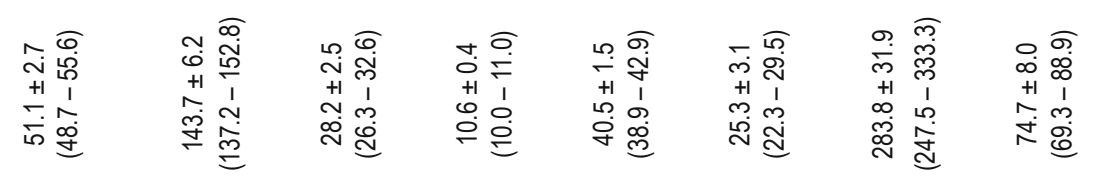

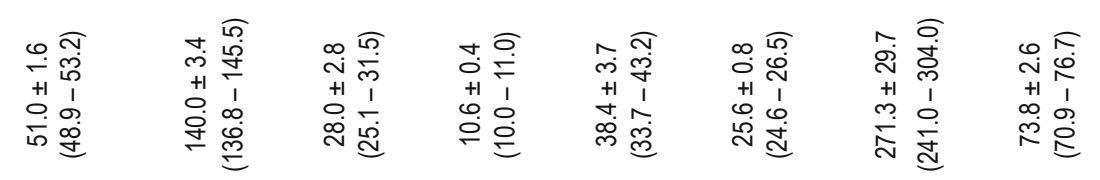

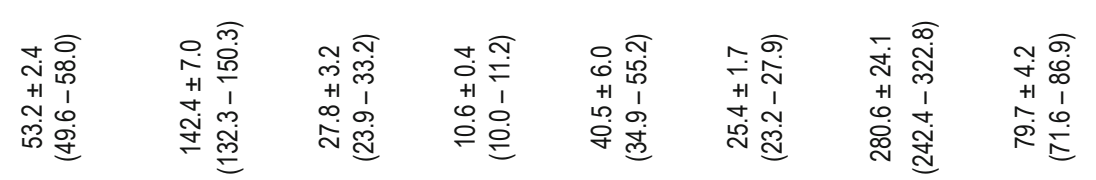

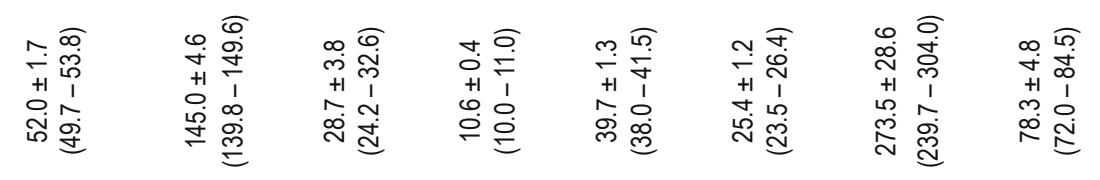

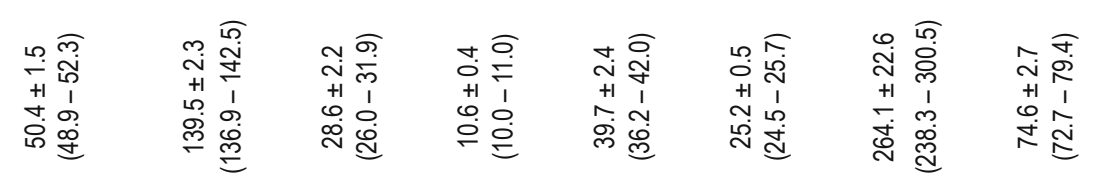

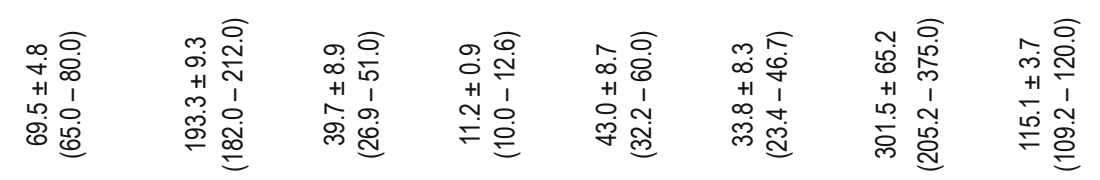

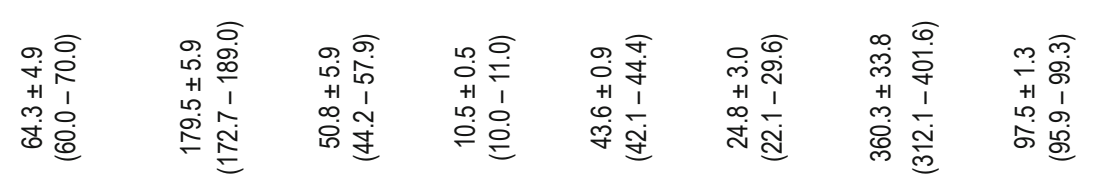

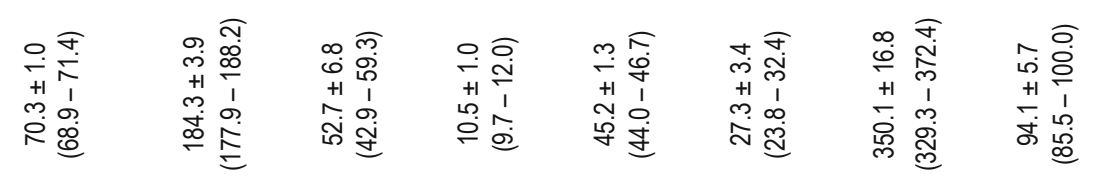

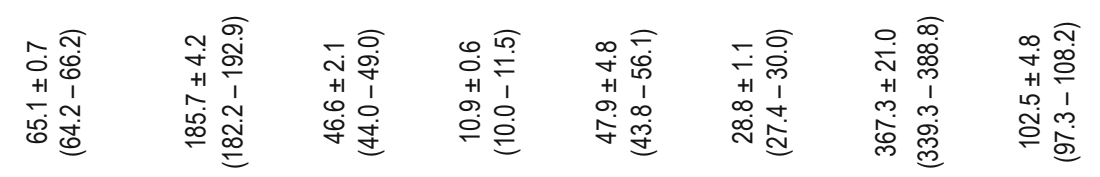

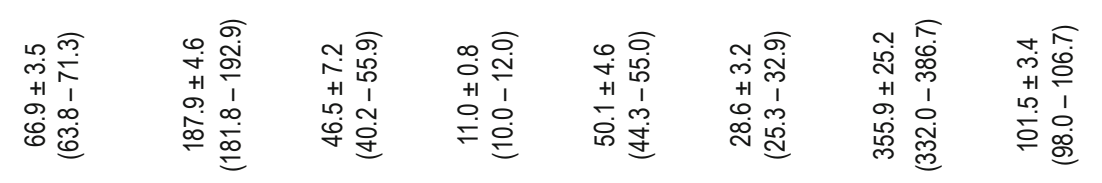

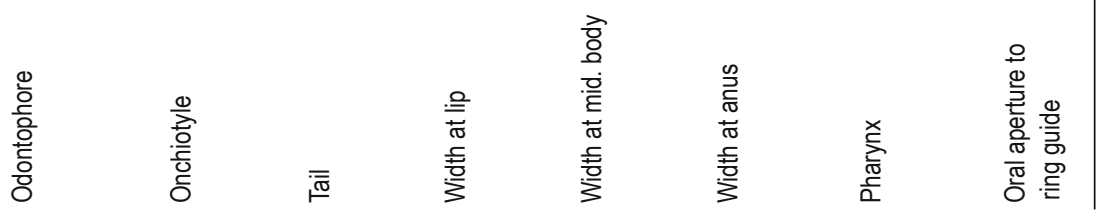


Male: Not found.

The morphology and morphometrics of four studied populations (SZX1301 - SZX1304) of $X$. hunaniense agreed with the description of type populations except for a lower a (39.7 - 52.7 vs 51.0 - 57.0) and c (37.1 - 51.6 vs 53.0 - 63.0) values (Wang \& Wu, 1992). A revised polytomous key code sensu Loof \& Luc (1990) for $X$. hunaniense identification is: A1-B4-C4-D4-E1-F2-G2-H2-I3J4-K2-L1.

Xiphinema brasiliense Lordello, 1951

(Fig. 2, Tables 1 \& 2)

Female: Body 1108-2100 $\mu \mathrm{m}$ long, cylindrical, straight or ventrally arcuate to form an open " $C$ " shape when heat-killed. Lip region continuous with the rest of the body or offset from body profile by a depression. Stylet $182-212 \mu \mathrm{m}$ long. Guide ring $109-120$ um from anterior end. Reproductive system monodelphic, with an anterior reflexed gonad. Vulva anteriorly located at $26 \%-29 \%$ of total body length, vagina $1 / 3$ to $1 / 2$ body diam. long, posteriorly obliquely bent. Tail broadly conoid ending with a well-developed axial peg, 8 - $12 \mu \mathrm{m}$ long. Four caudal pores present on each side of tail.

Male: Not found.

Xiphinema brasiliense population (SZX1305) agreed with type (Lordello, 1951) and other populations (Cordero, 2003), except for a higher $b$ and $c$ value (5.50 vs 5.05 and 41.60 vs 24.55 ) (LordelIo, 1951), but lie within the ranges of those reported by Cordero (2003). A revised polytomous key code sensu Loof and Luc (1990) for $X$. brasiliense identification is: A1-B4-C5-D5-E1-F2-G2(3)H1(2)-I3-J5-K?-L1.

Xiphinema americanum s.I. Cobb, 1913

(Fig. 3, Tables 1 \& 2)

Female: Body $1644-2110 \mu \mathrm{m}$ in length, cylindrical, tapering gradually towards the anterior extremity, and more abruptly posteriorly

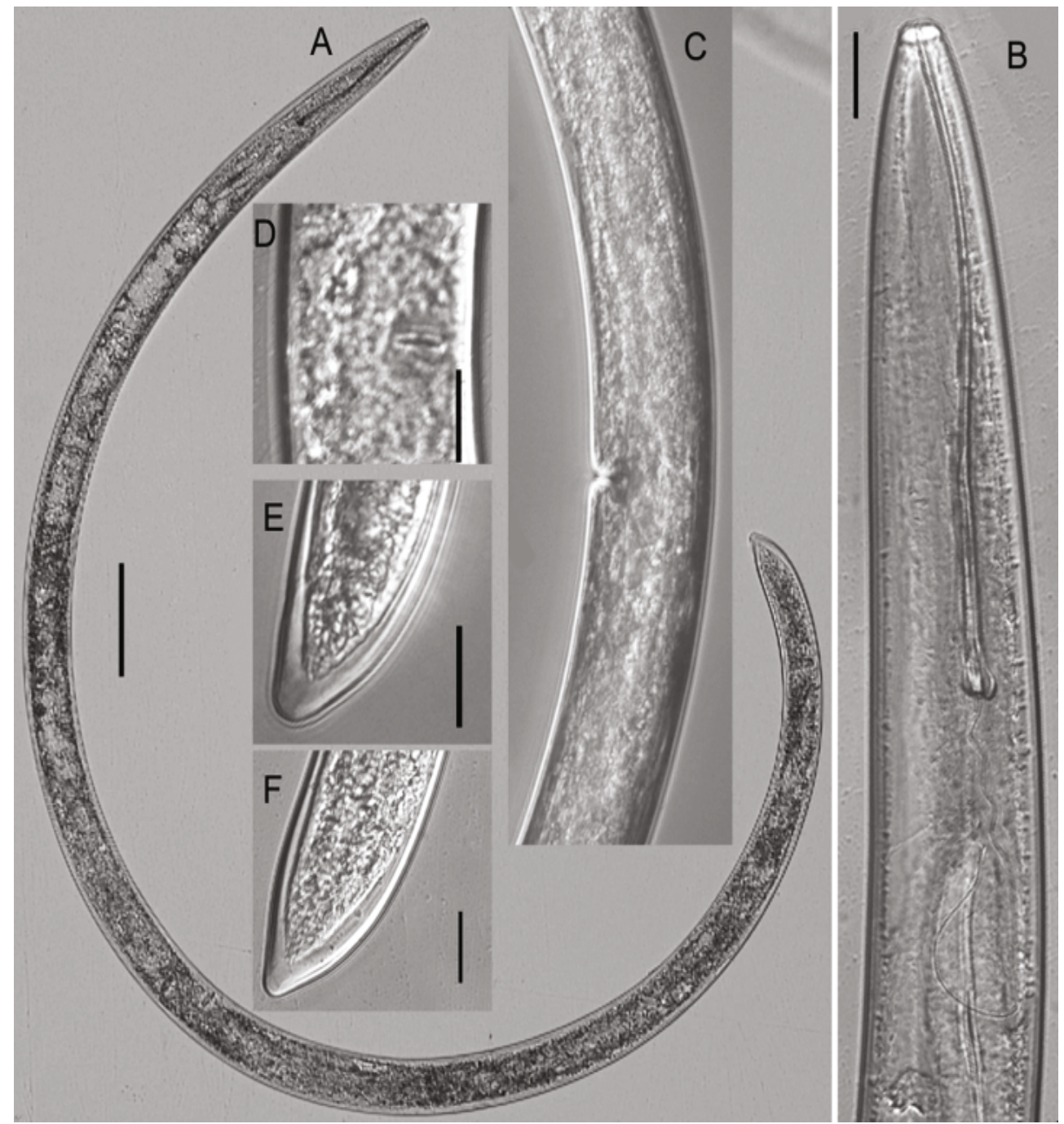

Fig. 3. Light micrographs of female Xiphinema americanum s.l. from Acacia mangium. A: Entire body; B: Anterior body; C: Reproductive system; D: Vulva (in ventral view); E: Tail in lateral view; F: Tail in ventral view. Scale bars: $A=100 \mu \mathrm{m} ; B-F=20 \mu \mathrm{m}$ 
in the tail region, ventrally arcuate to form a closed "C" shape when heat-killed. Cuticle finely transversely striated. Lip region broadly rounded, set off from the rest of body by a depression, $10-11 \mu \mathrm{m}$ in diam. Amphids large, stirrup-shaped, with wide aperture, as a straight transverse slit. Stylet $132-153 \mu \mathrm{m}$ long, basal flanges $7.5-9.5 \mu \mathrm{m}$ wide. Guiding ring $69-89 \mu \mathrm{m}$ from anterior end. Pharynx dorylaimoid with the anterior part tubular, bearing a strongly refringent mucro at $48-54 \mu \mathrm{m}$ from the base of the odontophore, pharyngeal basal bulb containing three nuclei, nucleus of dorsal pharyngeal gland located at $25 \%$ of the length from the beginning of basal bulb, and two ventro-sublateral nuclei situated at $50 \%$ of the bulb. Oesophago-intestinal valve heart-shaped. Reproductive system amphidelphic with reflexed branches about equally developed. Vulva slit-like, situated in mid-body region. Vagina 11 $-15 \mu \mathrm{m}$ in length, occupying about $1 / 3$ of the corresponding body diam., pars proximalis vaginae $5-6 \mu \mathrm{m}$ long, pars distalis vaginae $7-10 \mu \mathrm{m}$ long. Uteri long, 35 - $45 \mu \mathrm{m}$, not clearly separated from the oviduct, without spermatheca. Rectum length $1 / 2$ of the body diam. at anus. Tail short conoid, with rounded terminus and four lateral pores.

Table 3. The codes of the Chinese Xiphinema americanum s. populations five studied populations were classified as $X$. americanum s.l. due to limited diagnostic morphological characters and DNA data.

The codes of the Chinese Xiphinema americanum s.I. populations and close species using both $X$. americanum-group polytomous identification keys (Lamberti et al., 2000; Lamberti et al., 2004) were presented in Tables 3,4. The codes of the Chinese $X$. americanum s.l. populations are: A2, B2, C2, D1, E1(2), F1, G2, H2(3), I2, J2 sensu Lamberti et al. (2000) and A3(4), B2, C2, D2, E2, F1, G2, H2, I2 sensu Lamberti et al. (2004). Further, after sorting the codes with other data in the keys the Chinese populations showed identical numbers to some other species in $X$. americanum-group.

\section{Molecular Phylogenetic Relationships}

The 18S rDNA (633 - 796 bp) and 28S D2-D3 expansion segment $(773-860 \mathrm{bp})$ were amplified and sequenced. Sequences of the rDNA were compared using blastN search from a diverse collection of Xiphinema species from GenBank and were used to construct phylogenetic trees with highest match sequences.

The alignment for the partial 18S rDNA included 67 sequences. Four studied populations (KP793036 - KP793039) of $X$.

\begin{tabular}{lcccccccccc}
\hline Species/Codes & A & J & C & H & B & D & E & F & G & I \\
\hline X. americanum s.I. & 2 & 2 & 2 & $2(3)$ & 2 & 1 & $1(2)$ & 1 & 2 & 2 \\
X. taylori & 2 & 2 & 2 & $3(2)$ & $3(2)$ & 1 & 1 & $1(2)$ & 2 & $2(1)$ \\
X. diffusum & 2 & 2 & $2(1)$ & $2(1)$ & 2 & 1 & 1 & 1 & 2 & $1(2)$ \\
X. incognitum & 2 & 2 & $2(1)$ & $2(3)$ & $2(3)$ & $1(2)$ & 1 & 1 & $2(1)$ & 2 \\
X. brevicolle & 2 & 2 & $3(2)$ & 3 & $3(2)$ & 1 & $2(3)(1)$ & 1 & 2 & $2(1)$ \\
X. parabrevicolle & 2 & 2 & $3(2)$ & 3 & $3(2)$ & 1 & $2(1)$ & 1 & 2 & $1(2)$ \\
\hline
\end{tabular}

Male: Not found.

A morphometric analysis of five studied populations of $X$. americanum s.l. (SZX1306 - SZX1310) revealed that specimens from these populations differed from Cobb's paratypes of the $X$. americanum by having a longer body (1644 - 2106 vs $1400-1500 \mu \mathrm{m})$, a lower a value ( $38-50$ vs $50-57)$, a higher $\mathrm{c}$ value $(56-85$ vs $45-54)$, a lower c' value $(0.9-1.4$ vs $1.7-2.0)$, a longer odontostyle (83 - 108 vs $65-73 \mu \mathrm{m})$, a longer odontophore (49- 58 vs $41-46 \mu \mathrm{m})$ and a more posterior guide ring (71 - 89 vs $51-55$ $\mu \mathrm{m})$ (Lamberti \& Golden, 1984), from $X$. incognitum by having a smaller lip $(10.0$ - 11.2 vs $11.0-13.0 \mu \mathrm{m})$, from $X$. diffusum by having a smaller lip (10.0 - 11.2 vs $11.0-13.0 \mu \mathrm{m})$, a more posterior guide ring $(69.3-88.9$ vs $60.0-64.0 \mu \mathrm{m})$, from $X$. taylori by having a shorter (1644 - 2106 vs $2100-2500 \mu \mathrm{m})$, a higher c' value $(0.9-1.4$ vs $0.7-0.8)$ and a longer tail $(23.9-33.2$ vs $19.5-22.0 \mu \mathrm{m})$, from $X$. parabrevicolle by having a higher c' value (0.9-1.4 vs $0.7-0.8)$, a smaller lip (10.0 - 11.2 vs $12.5-14.0$ um) (Gutiérrez-Gutiérrez et al. 2012), from X. brevicolle by having a shorter stylet (137 - 143 vs 144 - $173 \mu \mathrm{m})$ (Lordello \& Costa 1961; Lamberti et al. 1991; Luc et al. 1998), a lower b value (5.3 -7.7 vs 7.0 - 10.5) (Lordello \& Costa 1961). Nevertheless, these hunaniense from China had $100 \%$ identities (647/647=100\%) based on alignments of the sequences of $18 \mathrm{~S}$ rDNA. No $18 \mathrm{~S}$ sequence of $X$. hunaniense was available for comparison in GenBank. Alignment of the $18 \mathrm{~S}$ sequences from the studied population (KP793040) of $X$. brasiliense from China with one Brazil population of $X$. brasiliense (AY297836) from GenBank revealed $99 \%$ identity (688/694=99\%). The sequences of $18 \mathrm{~S}$ rDNA from five studied populations (KP793041 - KP793045) of $X$. americanum s.l. from China shared $100 \%$ identities $(633 / 633=100 \%)$. These sequences are also identical to four other populations from Brazil (AY297822), Czech Republic (HM163212), Belgium (AY580057) and Japan (AB604340). However, the sequenced 18 S fragments are only 633 - 796 bp without sufficient divergent sites to examine the phyloge-

Table 4. The codes of the Chinese Xiphinema americanum s.I. populations and $X$. incognitum and $X$. brevicolle sensu Lamberti et al. (2004)

\begin{tabular}{lccccccccc}
\hline Species/Codes & G & H & A & C & B & D & E & F & I \\
\hline X. americanum s.I. & 2 & 2 & $3(4)$ & 2 & 2 & 2 & 2 & 1 & 2 \\
X. incognitum & 2 & 2 & 3 & 2 & 2 & 2 & 2 & 1 & 2 \\
X. brevicolle & 2 & 2 & $\underline{5}$ & $\underline{1}$ & 2 & 23 & 23 & 1 & 12 \\
\hline
\end{tabular}




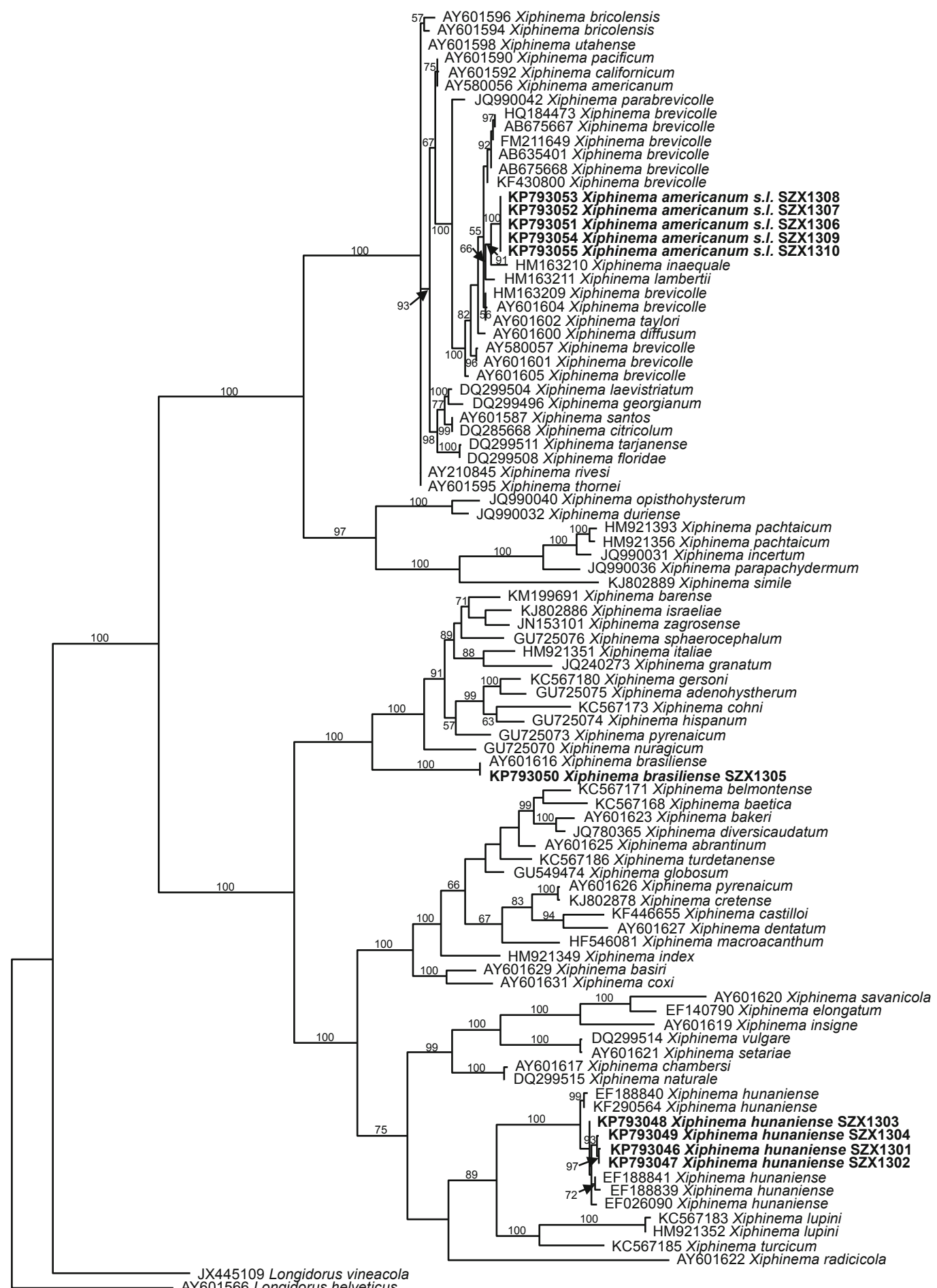

- 10 changes

Fig. 4. The 10001st Bayesian tree inferred from Xiphinema spp. 28S D2-D3 under GTR+I+G model $(-\ln L=10448.2939 ; A I C=20916.5879 ;$ freqA $=0.2519 ;$ freqC $=0.2207$; freqG $=0.3013$; freq $T=0.2261 ; R(a)=0.9498 ; R(b)=2.5514 ; R(c)=2.4833 ; R(d)=0.5243 ; R(e)=4.4187 ; R(f)=1 ;$ Pinva $=0.3354 ;$ Shape $=0.8037)$. Posterior probability values exceeding $50 \%$ are given on appropriate clades 
netic relationships among dagger species, no significant clades were generated with strong support, thus the $18 \mathrm{~S}$ tree is presented. The alignment for the D2-D3 of 28S rDNA included 93 sequences. The sequences of 28S rDNA from four studied populations (KP793046 - KP793049) of X. hunaniense shared $99 \%$ identities with 2 nucleotide differences. The alignment of the $28 S$ sequences from these four studied populations with other five populations of $X$. hunaniense (EF026090, EF188839, EF188840, EF188841, KF290564) from GenBank revealed $98 \%$ - $99 \%$ identities with 6 14 nucleotide differences. The blastn search of the $28 \mathrm{~S}$ sequence of the Chinese population (KP793050) of $X$. brasiliense revealed a $99 \%$ match $(763 / 766=99 \%, 3$ nucleotide differences) with one Brazilian population of $X$. brasiliense (AY601616) from GenBank. Five studied populations (KP793051 - KP793055) of X. americanum s.l. shared $99 \%-100 \%$ identities with $0-9$ nucleotide differences. The alignment of the $28 \mathrm{~S}$ sequences from these five studied populations with 11 populations of $X$. brevicolle (AB635401, AB675667, AB675668, AY580057, AY601601, AY601604, AY601605, FM211649, HM163209, HQ184473, KF430800) and some other species such as $X$. lambertii (HM163211), $X$. diffusum (AY601600), X. taylori (AY601602), etc. from GenBank revealed $98 \%$ - $99 \%$ identities with $10-20$ nucleotide differences.

The phylogenetic tree inferred from D2-D3 of the 28S rDNA (Fig. 4) using Longidorus vineacola Ye \& Robbins, 2003 and L. helveticus Lamberti, Kunz, Grunder, Molinari, De Luca, Agrostinelli \& Radicci, 2001 as outgroups suggested that: i) all the selected xiphinematids are in a monophyletic clade in relation to $L$. vineacola with $100 \%$ pp; ii) two distinct clades of Xiphinema species are highly supported $(\mathrm{pp}=100 \%)$, representing $X$. americanum-group and non- $X$. americanum-group. In $X$. americanum-group, seven populations (HM921393, HM921356, KJ802889, JQ990031, JQ990032, JQ990036, JQ990040) are in a clade and 35 other populations including five studied ones of $X$. americanum s.l. (KP793051 - KP793055) are in another clade with $100 \%$ support; iii) five studied populations of $X$. americanum s.l. are in a monophyletic clade with $100 \%$ support, and are in a highly-supported $(\mathrm{pp}=100 \%$ ) monophyletic clade with 16 other populations of Xiphinema, and they are sister to $X$. parabrevicolle (JQ990042); iv) four studied populations of $X$. hunaniense (KP793046 KP793049) and the population of $X$. brasiliense (KP793050) are clustered with other members of non- $X$. americanum-group, and these two species are in two separate clades; $v$ ) four studied populations of $X$. hunaniense are in a highly-supported $(\mathrm{pp}=100 \%)$ monophyletic clade with five other populations of $X$. hunaniense (EF026090, EF188839, EF188840, EF188841, KF290564) from GenBank, and they are sister to X. Iupini (KC567183, HM921352) and $X$. turcicum (KC567185); v) the studied population X. brasiliense (KP793050) is in a highly-supported ( $p p=100 \%$ ) clade with the Brazilian population of $X$. brasiliense (AY297836), and they are in a highly-supported ( $p p=100 \%$ ) clade with 12 other species (X. nuragicum, $X$. pyrenaicum, $X$. hispanum, $X$. adenohystherum, $X$. sphaerocephalum, $X$. italiae, $X$. zagrosense, $X$. granatum,
X. cohni, X. gersoni, X. israeliae, X. barense) from GenBank.

\section{Discussion}

Species identification on Xiphinema americanum-group is difficult or even impossible due to conservative and overlapping morphological and morphometric characters. This group may contain many cryptic species that are morphologically indistinguishable but may be phylogenetically distant to one another (Gutiérrez-Gutiérrez et al. 2010, 2012; Barsi \& De Luca 2008; Oliveira et al. 2005, 2006; Wu et al. 2007; Ye et al. 2004). In the present study, analysis of morphology and morphometrics indicated that five studied populations (SZX1306 - SZX1310) were very similar to some members belonging to $X$. americanum-group. The codes of these five populations using polytomous identification keys revealed identical numbers to some other species in this group such as $X$. incognitum (Tables 3,4). Molecular analysis based on D2-D3 of 28S rDNA sequences revealed that these five studied populations and other members within $X$. americanum-group such as $X$. brevicolle show high similarity. Thus, these five studied populations were classified as $X$. americanum s.I.. Compared with $X$. incognitum from Fujian (Wu 2007) and Japan (Shishida 1983), a closest species to the Chinese $X$. americanum s.l., no obvious morphometrics difference was found. The identification codes of these two species revealed identical numbers. However, $28 S$ rDNA sequence alignment of five populations of the Chinese $X$. americanum s.l. with an American population (AY601597) of $X$. incognitum in GenBank revealed $96 \%$ identity with 27 nucleotide differences. In addition to D2-D3 of 28S rDNA, other molecular markers, such as ITS-rRNA and the protein-coding mitochondrial gene, cytochrome oxidase $c$ subunit I (COI) were successfully used for diagnosis and reconstruction of phylogenetic relationships within some species of $X$. americanum-group (Gutiérrez-Gutiérrez et al. 2012; Lazarova et al., 2006). In the future, sequencing these markers on five studied populations of $X$. americanum s. $I$. will help to characterize this species and investigate its phylogenetic relationship with other sequenced dagger species.

Morphological intraspecific variation in dagger nematodes from different geographic locations is common (Tarjan, 1969; Brown \& Topham, 1985; Cho \& Robbins, 1991). In the present study, no obvious differences were found in morphological and morphometric characters amongst four populations of $X$. hunaniense (SZX1301 SZX1304) and amongst five studied populations of $X$. americanum s.l. from two sites and five plants. This is largely due to the sampling being from the same sites, the same city or the same hosts; for example, two populations (SZX1301 \& SXZ1302) of X. hunaniense were from the same host $(B$. orientale) in different spots of the same site (Tianxinshan), so were $X$. americanum s.l. populations, SZX1307 and SXZ1308 (Table 1). Compared with other populations, most of the morphological characteristics from populations of $X$. hunaniense fit within the ranges of previous reports (Wang \& Wu, 1992; Robbins \& Wang, 1998; Zheng \& Brown, 1999). The minor differences were only present in a few characters such as a 
and $c$ values. However, the molecular data confirmed identity of this species. Morphometrics of the studied $X$. brasiliense population agreed with those of type population except for $b$ and $c$ values, but the analysis of the 28S D2-D3 rDNA sequences revealed their identity. Therefore, all these morphological differences amongst populations were considered as intraspecific variation.

Xiphinema hunaniense and $X$. brasiliense belong to $X$. radicicola-group. They are difficult to separate in morphology both possessing a relatively short body size, an anteriorly situated vulva and a simple posterior uterus lacking a " $Z$ " organ or other ornamentation, but can be differentiated by sequence of 28S D2-D3 expansion region (Wu et al., 2007). In this study, a comparison of the ranges of the morphometrics of females from $X$. hunaniense and $X$. brasiliense showed that most characters are partialy overlapping except for a lower c' value $(1.0-1.3$ vs $1.5-2.6)$ and a more posterior guide ring $(109-120$ vs $86-108 \mu \mathrm{m})$ of $X$. brasiliense (Table 1). However, analysis of molecular data (28S D2-D3 rDNA) of these two species indicated their identify being only $89 \%-90 \%$ (110 - 112 nucleotide differences). Molecular phylogenetic analysis based on sequences of the 28S D2-D3 expansion region revealed that they are in separate clades (Fig. 4). Xiphinema hunaniense was once considered as a junior synonym of $X$. radicicola (Loof et al., 1996), but it was re-established as a valid species by Robbins \& Wang (1998) and Zheng \& Brown (1999). Alignment of sequences of the 28S D2-D3 expansion region from $X$. hunaniense and a Vietnam population of $X$. radicicola indicated that they have $83 \%$ identity with 153 nucleotide differences. Molecular phylogenetic analysis based on sequences of the 28S D2-D3 revealed that they are clearly different species (Fig. 4). Thus these three species are all valid species and can be differentiated by molecular data of 28S D2-D3 rDNA.

Xiphinema brasiliense has been found in Brazil (Lordello, 1951), Guatemala, Ceylon and Nigeria (Cohn \& Sher, 1972), the Ivory Coast and Australia (Luc, 1981), Peru (Alkemade \& Loof, 1990), India (Loof et al., 2001), Venezuela (Cordero, 2003), Taiwan (Ni et al., 2003; Chen et al., 2004), China (Wu, 2007). Liu et al. (1995) identified a population from Sageretia theezans Brongn in Guangdong as $X$. brasiliense only based on morphology, but Song et al. (1998) considered this population as $X$. hunaniense by morphological observation compared with a population of $X$. hunaniense from bonsai in Shanghai. In this study, a comparison of the ranges of the morphometrics of females from $S$. theezans in Guangdong (Liu et al., 1995) and our population of $X$. brasiliense from Gleichenia linearis in Shenzhen, Guangdong revealed that almost all characters of both populations are very similar except for a more anteriorly-located guide ring from the $S$. theezans population (94108 vs $109-120 \mu \mathrm{m}$ ) (Table 2). Sequence analysis of the $28 \mathrm{~S}$ D2-D3 supported species identity of our population. Therefore, it is necessary to identify species of nematodes by combination of morphological and molecular data. So far, $X$. brasiliense has been reported from various hosts including Solanum tuberosum L., Litchi chinensis, Citrus sp. L., Mangifera indica L., Persea america- na Mill., Musa sp. L., Saccharum officinarum L., Sorghum bicolor L., Andropogum bicornis L., Clidermia hirta L. D. Don., Prunus persica L., Euterpes edulis Mart., and Butia capitata (Mart.) Becc. (Alkemade \& Loof, 1990; Cordero, 2003; Diaz-Silveira \& Herrera, 1998; Lordello, 1951; Oliveira et al., 2003; Wu, 2007). Gleichenia linearis is a new host record for $X$. brasiliense.

Xiphinema americanum s.l. and $X$. hunaniense have been reported from China. Xiphinema_americanum s.l. is reported from Jiangsu, Zhejiang, Hunan, Guangxi, Shandong, Hebei and Inner Mongolia, Sichuan, Yunnan (CABI, 2011; Wang \& Wu, 1992; Xu et al., 1995). Xiphinema hunaniense is reported from Hunan, Zhejiang, Guangxi, Fujian, and Shanghai (Pan et al., 2000; Wang et al., 1996; Wang \& Wu, 1992; Xu et al., 1995; Wu et al., 2007; Song et al., 1998). Our study added new records to the list. These two species are associated with various plants. Xiphinema hunaniense has been reported from Camellia japonica L., Citrus grandis (L.) Osbeck, Citrus sinensis (L.) Osbeck, Cycas revolute L., Euphoria Iongana Lam., Eriobotrya japonica Lindl., Vitis vinifera L., Hibiscus rosasinensis L., Litchi chinensis, Mangifera indica, Pyrus pyrifolia var. yokoyama, Pinus sp. L., Prunus sp. L., Buxus sinica L., Camellia sasanpua L., Ligustrum quihoui L., L. lucidum L. and Juniperus chinensis L. (Chen et al., 2004; Long et al., 2014; Wu et al., 2007; Zheng et al., 1999 ) and X. americanum s.l. from agricultural, horticultural and forest soils, including Agropyron cristatum Gaertn., Amygdalus persica L., Castanea mollissima Bl., Citrus aurantium L., Coffea arabica L., Crataegus sp. L., Cynodon dactylon Pers., Daucus carota L., Diospyros kaki Thunb., Eucalyptus tereticornis Sm., Fragaria sp. L., Ilex crenata Thunb., Juglans regia L., Ligustrum sp. L., Litchi chinensis, Malus sp. Mill., Persea americana, Podocarpus macrophyllus L., Pyrus sp. L., Rosa indica L., Urtica urens L., Vitis sp. L., Zea mays L. (Brodie et al., 1969; Cohn, 1969; Cohn \& Mordechai, 1969; Cohn \& Orion, 1970; Cho et al., 1991; Goodey et al., 1965; Griffin et al., 1996; Morton, 1987; Norton \& Varon De Agudelo, 1984; Sakai et al., 2011; Siddiqui et al., 1973; Wang et al., 1992; Zhao et al., 2012). To our knowledge, this is the first report of $X$. hunaniense on $B$. orientale and $G$. linearis and $X$. americanum s.I. on $A$. mangium, $A$. confuse and $B$. orientale.

\section{Acknowledgements}

The authors would like to thank Mr. Zhicong Li and Mr. Haohui Li for assistance with soil sample collection. This study was supported by a grant from Shenzhen Residential and Environmental Committee, China (SZGX2012118F-SCZJ). The first author received a co-scholarship of China Scholarship Council and Guangdong Department of Education.

\section{References}

Alkemade, J. R. M., Loof, P. A. A. (1990): The genus Xiphinema Cobb, 1913 (Nematoda: Longidoridae) in Peru. Rev. Nématol., 13: $339-348$ 
BARSI, L., DE LUCA, F. (2008): Morphological and molecular characterization of two putative Xiphinema americanum-group species, $X$. parasimile and $X$. simile (Nematoda: Dorylaimida) from Serbia. Nematology, 10: $15-25$

Brodie, B. B., Good, J. M., Adams, W. E. (1969): Population dynamics of plant nematodes in cultivated soil: effect of sod-based rotations in cecil sandy loam. J. Nematol., 1: $309-312$

Brown, D. J. F., BoAg, B. (1988): An examination of methods used to extract virus-vector nematodes (Nematoda: Longidoridae and Trichodoridae) from soil samples. Nematol. Mediterr., 16: 93 - 99 Brown, D. J. F., Topнam, P. B. (1985): Morphometric variability between populations of Xiphinema diversicaudatum (Nematoda: Dorylaimoidea). Rev. Nematol., 8: 15 - 26

CABI. (2011): Xiphinema brevicollum Lordello \& Da Costa. [Distribution map]. Distribution Maps of Plant Diseases (October) (1 $1^{\text {st }}$ Edition), Map 1119

Chen, D., Ni, H., Yen, J., Cheng, Y., Tsay, T. (2004): Identification and variation of Xiphinema hunaniense populations from Taiwan. Plant Pathol. Bull., 13: 155 - 166

Cho, M. R., RobBins, R. T. (1991): Morphological variation among 23 Xiphmema americanum populations. J. Nematol., 23: 134 - 144 CoHN, E. (1969): The occurrence and distribution of species of Xiphinema and Longidorus in Israel. Nematologica, 15: 179 - 192 CoHn, E., ORION, D. (1970): The pathological effect of representative Xiphinema and Longidorus species on selected host plants. Nematologica, 16: 423 - 428

Cohn, E., Mordechal, M. (1969): Investigations on the life cycles and host preference of some species of Xiphinema and Longidorus under controlled conditions. Nematologica, 15: 295 - 302

COHn, E., SHeR, S. A. (1970): A contribution to the taxonomy of the genus Xiphinema COBB, 1913. J. Nematol., 4: $36-65$

Coomans, A. (1996): Phylogeny of the Longidoridae. Russ. J. Nematol., 4: $51-60$

Coomans, A., Huys, R., Heyns, J., Luc, M. (2001): Character analysis, phylogeny, and biogeography of the genus Xiphinema Cobb, 1913 (Nematoda: Longidoridae). Annales du Musée Royal de l'Afrique Centrale (Zoologie), Tervuren, Belgique, 287: 1 - 239

Cordero, M. (2003): Morphometrics of a population of Xiphinema brasiliense (Nematoda, Dorylaimida) from Tachira, Venezuela. Nematol. Mediterr.,31: $39-41$

Decraemer, W., Robbins, R. T. (2007): The who, what and where of Longidoridae and Trichodoridae. J. Nematol., 39: 295 - 297

Diaz-Silveira, M. F., Herrera, J. O. (1998): An overview of nematological problems in Cuba. Nematropica, 28: $151-163$

Golden, A. M. (1990): Preparation and mounting nematodes for microscopic observation. In: Zuckerman, B. M., Mal, W. F., KRusBERg, L. R. (Eds) Plant Nematology Laboratory Manual. Revised Edition, Amherst, MA, USA: University of Massachusetts Agricultural Experiment Station, pp. $197-205$

Golden, A. M., BIRChFIELD, W. (1972): Heterodera graminophila n. sp. (Nematoda: Heteroderidae) from grass with key to closely related species. J. Nematol., 4: 147 - 154
Goodey, J. B., Franklin, M. T., Hooper, D. J. (1965): The Nematode Parasites of Plants Catalogued Under Their Hosts. Commonwealth Agricultural Bureaux, Farnham Royal, Bucks, England. $3^{\text {th }}$ Edition, 214pp.

Griffin, G. D., Asay, K. H., HoRton, W. H. (1996): Factors affecting population trends of nematodes on rangeland grasses. J. Nematol., 28: $107-114$

Gutiérrez-Gutiérrez, C., Palomares-Rius, J., Cantalapiedra-Navarrete, C., Landa, B. B., Esmenjaud, D., Castillo, P. (2010): Molecular analysis and comparative morphology to resolve a complex of cryptic Xiphinema species. Zool. Scr., 39: 483 - 498. DOI: 10.1111/j.1463-6409.2010.00437.x

Gutiérrez-Gutiérrez, C., Cantalapiedra-Navarrete, C., Decraemer, W., Vovlas, N., Prior, T., Palomares-Rius, J., Castillo, P. (2012): Phylogeny, diversity, and species delimitation in some species of the Xiphinema americanum-group complex (Nematoda: Longidoridae), as inferred from nuclear and mitochondrial DNA sequences and morphology. Eur. J. Plant Pathol., 134: 561 - 597

Gutiérrez-GutiéRrez, C., Cantalapiedra-Navarrete, C., Remesal, E., Palomares-Rius, J. E., Navas-CortéS, J. A., Castillo, P. (2013): New insight into the identification and molecular phylogeny of dagger nematodes of the genus Xiphinema (Nematoda: Longidoridae) with description of two new species. Zool. J. Linn. Soc., 169: 548 - 579 He, Y., Subbotin, S. A., Rubtsova, T. V., Lamberti, F., Brown, D. J. F., Moens, M. (2005): A molecular phylogenetic approach to Longidoridae (Nematoda: Dorylaimida). Nematology, 7: 111 - 124

HOOPER, D. J. (1970): Handling, fixing, staining and mounting nematodes. In: SoutHEY, J. F. (Ed) Laboratory Methods For Work With Plant And Soil Nematodes. $5^{\text {th }}$ Edition, London: Her Majesty's Stationery Office, pp. $39-54$

HuelsenbeCK, J. P., Ronquist, F. (2001): Mr Bayes: Bayesian inference of phylogenetic trees. Bioinformatics, 17: $1754-1755$

LAmBertI, F., Golden, A. M. (1984): Redescription of Xiphinema americanum Cobb, 1913 with comments on its morphometric variations. J. Nematol., 14: $204-206$

Lamberti, F., Hockland, S., Agostinelli, A., Moens, M., Brown, D. J. F. (2004): The Xiphinema americanum group. 3. Keys to species identification. Nematol. Mediterr., 32: $53-56$

Lamberti, F., Molinari, S., Moens, M., Brown, D. J. F. (2000): The Xiphinema americanum-group. I. Putative species, their geographical occurrence and distribution, and regional polytomous identification keys for the group. Russ. J. Nematol., 8: $65-84$

Lamberti, F., Ciancio, A., Agostinelli, A., Coiro, M. I. (1991): Relationship between Xiphinema brevicolle and $X$. diffusum with a redescription of $X$. brevicolle and descriptions of three new species of Xiphinema (Nematoda: Dorylaimida). Nematol. Mediterr., 19: $311-326$

LARGet, B., Simon, D. L. (1999): Markov Chain Monte Carlo algorithms for the Bayesian analysis of phylogenetic trees. Mol. Biol. Evol., 16: $750-759$

Lazaroa, S. S., Mallock, G., Oliveira, C. M. G., Hubschen, J., Neilson, R. (2006): Ribosomal and mitochondrial DNA analyses of 
Xiphinema americanum-group populations. J. Nematol., 38: 404 $-410$

Liu, J., Wang, D., Chen, J., Ye, B., Huang, G. (1995): The new record of Xiphinema brasiliense for China and the observation of this nematode larvae. Plant Quarant. (Shanghai), 9: 327 - 330 (In Chinese)

Long, H., LING, X., LI, Y., Zheng, Y. (2014): Molecular and morphological identification of Xiphinema hunaniense on the Juniperus chinensis imported from Thailand. Plant Pathol. Quarant., 4: 92 $-98$

Loof, P. A. A., Coomans, A., Baujard, P., Luc, M. (2001): On five species of the genus Xiphinema Cobb, 1913 (Nematoda: Longidoridae) recently described from India. Nematology, 3: 277 - 283

LoOF, P. A. A., LUC, M, BAuJARD, P. (1996): A revised polytomous key for the identification of species of the genus Xiphinema Cobb, 1913 (Nematoda: Longidoridae) with exclusion of the $X$. americanum-group: Supplement 2. Syst. Parasitol., 33: 23 - 29

Loof, P. A. A., Luc, M. (1990): A revised polytomous key for the identification of species of the genus Xiphinema Cobb, 1913 (Nematoda: Longidoridae) with exclusion of the $X$. americanum-group. Syst. Parasitol., 16: $35-66$

LoRdello, L. G. E., Costa C. P. (1961): A new nematode parasite of coffee roots in Brazil. Rev. Bras. Biol., 21: 363 - 366

LORdelLo, L. G. E. (1951): Xiphinema brasiliense, nova espécie de nematóide do Brasil, parasita de Solanum tuberosum L. Bragantia, 11: $87-90$

Luc, M. (1981): Observations on some Xiphinema species with the female anterior genital branch reduced or absent (Nematoda: Longidoridae). Rev. Nématol., 4: 157- 167

Luc, M., Coomans, A., Loof, P. A. A., Baujard, P. (1998): The Xiphinema americanum-group (Nematoda: Longidoridae). 2. Observations on Xiphinema brevicollum Lordello \& da Costa, 1961 and comments on the group. Fund. Appl. Nematol., 21: $475-490$

Luo, S., Zhangsun, D., He, P. (2001): Investigation of Xiphinema species around grape roots from four provinces of China. Acta Horticu. Sin., 28: 451 - 452 (In Chinese)

Morton, J. (1987): Lychee. In: Fruits of warm climates. USA: Miami, FL, pp. 249 - 259

Mullin, P. G., Harris, T. S., Powers, T. O. (2005): Phylogenetic relationships of Nygolaimina and Dorylaimina (Nematoda: Dorylaimida) inferred from small subunit ribosomal DNA sequences. Nematology, 7: 59 - 79. DOI: 10.1163/1568541054192199

Ni, H. F., Cheng, Y. H., Chen, R. S., TSAY, T. T., Chen, D. Y. (2003): Discrimination of Xiphinema species from Taiwan by rDNA-RFLP analysis. Plant Pathol. Bull., 12: 235 - 241

Norton, D. C., Varon De Agudelo, F. (1984): Plant-parasitic nematodes associated with maize in Cauca and Valle del Cauca, Colombia. Plant Dis., 68: 950 - 952

Nunn, G. B. (1992): Nematode Molecular Evolution. PhD dissertation. UK: University of Nottingham

Oliveira, C. M. G., Brown, D. J. F., Neilson, R., Monteiro, A. R., Ferraz, L. C. C. B., Lamberti, F. (2003): The occurrence and geo- graphic distribution of Xiphinema and Xiphidorus species (Nematoda: Longidoridae) in Brazil. Helminthologia, 40: 41 - 54

Oliveira, C. M. G., Hübschen, J., Brown, D. J. F., Ferraz, L. C. C. B., Wright, F., NeILSON, R. (2004): Phylogenetic relationships among Xiphinema and Xiphidorus nematode species from Brazil inferred from 18S rDNA sequences. J. Nematol., 36: 153 - 159

Oliveira, C. G., Fenton, B., Malloch, G., Brown, D. J. F., Neilson, R. (2005): Development of species-specific primers for the ectoparasitic nematode species Xiphinema brevicolle, $X$. diffusum, $X$. elongatum, $X$. ifacolum and $X$. longicaudatum (Nematoda: Longidoridae) based on ribosomal DNA sequences. Ann. Appl. Biol., 146: 281- 288

Oliveira, C. M. G., Ferraz, L. C. C. B., Neilson, R. (2006): Xiphinema krugi, species complex or complex of cryptic species? J. Nematol., 38: 418 - 428

Pan, C. S., Zheng, J. W., Zhou, X. P., Nellson, R., Brown, D. J. F. (2000): Preliminary assessment of the occurrence of longidorid and trichodorid nematodes (Nematoda: Longidoridae and Trichodoridae) in Xiamen, Fujian Province, China. Russ. J. Nematol., 8: $153-159$

Posada, D., Criandall, K. A. (1998): Modeltest: testing the model of DNA substitution. Bioinformatics, 14: 817 - 818

RobBins, R. T., Wang, S. (1998): A comparison between Xiphinema radicicola and $X$. hunaniense. In Program and abstracts of the $24^{\text {th }}$ international symposium of the European Society of Nematologists, 4 - $9^{\text {th }}$, August 1998, Dudee, Scotland, 100.

Sakal, H., TAKeda, A., Mizukubo, T. (2011): First report of Xiphinema brevicolle Lordello et Costa,1961 (Nematoda: Longidoridae) in Japan. ZooKeys, 135: 21 - 40

doi: 10.3897/zookeys.135.1716

SHISHIDA, Y. (1983): Studies on nematodes parasitic on woody plants. 2. Genus Xiphinema Cobb, 1913. Japanese J. Nematol., 12: $1-14$

Siddiqui, I. A., Sher, S. A., French, A. M. (1973): Distribution of Plant Parasitic Nematodes in California. State of California Department of Food and Agriculture, Division of Plant Industry, 324pp.

Song, S., GaO, H., ZHou, G. (1998): Plant parasitic nematodes of bonsai in Shanghai. I. Xiphinema hunaniense - new record in Shanghai. Acta Agric. Shanghai, 14: 73 - 75 (In Chinese)

TARJAN, A. C. (1969): Variation within Xiphinema americanum group (Nematoda: Longidoridae). Nematologica, 15: 241 - 252

TAYLOR, C. E., Brown, D. J. F. (1997): Nematode Vectors of Plant Viruses. Wallingford, UK: CAB International, 296pp.

Teng, W., Tan, J., Ye, J., Fang A. (2013): Aphelenchida and Xiphinema spp. from rhizosphere of ornamental trees in Nanjing, eastern China. J. Beijing For. Univ., 35: 88 - 94 (In Chinese)

WANG, S., Wu, X., ZHANG, C. (1992): Occurrence and distribution of Xiphinema americanum in orchard in Jiaodong peninsula, China. Decidous Fruits, 2: 23 - 24 (In Chinese)

Wang, S., Wu, X. (1992): Two species of Xiphinema Cobb, 1913 (Dorylaimida: Longidoridae) from around grape roots in China. Acta Phytopathol. Sin., 22: 117 - 123 (In Chinese) 
Wang, S., ChiU, W. F., Yu, C., LI, C., Robbins, R. T. (1996): The occurrence and geographical distribution of longidorid and trichodorid nematodes associated with vineyards and orchards in China. Russ. J. Nematol., 4: 145 - 153

Williams, B. D., Schrank, B., Huynh, C., Shownkeen, R., Waterston, R. H. (1992): A genetic mapping system in Caenorhabditis elegans based on polymorphic sequence-tagged sites. Genetics, 131: 609 $-624$

WU, Y., ZHENG, J., RoBBINs, R. T. (2007): Molecular Characterization of a Xiphinema hunaniense population with morphometric data of all four juvenile stages. J. Nematol., 39: $37-42$

Wu, Y. (2007): Studies on morphology and molecular classification of major populations of the genus Xiphinema in China. PhD dissertation, China: Zhejiang University (In Chinese)

Xu, J., Fu, P., CHENG, H. (1995): A taxonomic study on species of Xiphinema from seven provinces of China (Nematoda: Longidoridae). J. Nanjing Agric. Univ., 18: 37 - 42

YE, W. (1996): Applying Microsoft Works spread sheet in statistics for morphometric data of nematode identification. Afro-Asian J. Nematol., 6: $203-211$

Ye, W., Giblin-Davis, R. M., Braasch, H., MorRis, K., Thomas, W. K. (2007): Phylogenetic relationships among Bursaphelenchus species (Nematoda: Parasitaphelenchidae) inferred from nuclear ribosomal and mitochondrial DNA sequence data. Mol. Phylogenet. Evol., 43: 1185 - 1197. DOI: 10.1016/j.ympev.2007.02006

Ye, W., Szalanski, A. L., Robbins, R. T. (2004): Phylogenetic relationships and genetic variation in Longidorus and Xiphinema species (Nematoda: Longidoridae) using ITS1 sequences of nuclear ribosomal DNA. J. Nematol., 36: $14-19$

ZHENG, J., BRown, D. J. F. (1999): Xiphinema insigne LOOS, 1949 and $X$. hunaniense WANG \& WU, 1992 from Hangzhou, China, and synonymization of $X$. savaryi Lamberti, Troccoli \& Agostinelli, 1997 with $X$. insigne, and $X$. siamense Lamberti, Troccoli \& Agostinelli, 1997 with X. radicicola Goodey, 1936 (Nematoda: Longidoridae). Russ. J. Nematol., 7: 127 - 137 